\title{
The threat of mine effluent to the UNESCO status of the Cradle of Humankind World Heritage Site
}

\author{
JF DURAND, ${ }^{*}$ J MEEUVIS ${ }^{* *}$ AND M FOURIE ${ }^{* * *}$
}

\begin{abstract}
There is a significant environmental risk posed to the region in which one of the most important and richest archaeological and palaeontological resources is located in South Africa. This area, known as the Cradle of Humankind World Heritage (COHWHS), is situated adjacent to one of the richest gold bearing geological sequence in the world. The mine pollution which is emanating from the mines in the form of acid mine drainage (AMD) is threatening this remarkable resource which has yielded the biggest collection of hominin fossils in the world. The environmental degradation of the COHWHS will have a major impact on the archaeological and palaeontological heritage of not only South Africa, but the world, as well as the tourism, hospitality and education sectors of South Africa. If monitoring, mitigation and management measures are not implemented effectively with immediate effect to avoid or minimise the negative effects, the COHWHS may stand the risk of losing its status and be demoted to the UNESCO List of World Heritage in Danger. Ultimately, if the site loses the characteristics that determined its inscription in the World Heritage List, the World Heritage Committee may decide to delete the property from its list.
\end{abstract}

Keywords: Cradle of Humankind World Heritage Site, Sterkfontein Caves, acid mine drainage, archaeological and palaeontological resources, dolomite, karst system, risks and impacts

Disciplines: Environmental management, Palaeontology, Archaeology

\section{Introduction}

The Cradle of Humankind to the north of Krugersdorp on the West Rand in Gauteng was awarded World Heritage Site status by the United Nations Educational, Scientific and Cultural

Department of Zoology, University of Johannesburg; (all correspondence should be sent to: fdurand@uj.ac.za).

Department of Geography and Environmental Management and Energy Studies, University of Johannesburg.

PhD candidate in the Department of Geography and Environmental Management and Energy Studies, University of Johannesburg.

TD The Journal for Transdisciplinary Research in Southern Africa, 6(1) July 2010, pp. 73-92. 
Organization (UNESCO) in 1999. Its status is based on the unique cultural and natural heritage contained within this area.

The Cradle of Humankind World Heritage Site is a remarkable South African tourist attraction and is also acknowledged as an important research resource. The sensitive karst system, in which the Cradle of Humankind World Heritage is situated, is threatened by urban development and the unauthorized removal of dolomite, cave formations, fossils and archaeological artefacts by the public, as well as the over-use of natural resources and pollution in the area (Durand, 2008). The acidic water decanting from the West Rand pose the most severe immediate threat to the sensitive and soluble dolomite rock which contains most of the important palaeontological and archaeological sites of the Cradle of Humankind World Heritage Site however (Van Eeden et al., 2009).

If these negative impacts are not mitigated in time or become more severe, the Cradle of Humankind World Heritage Site could be placed on the list of world heritage sites under threat or even may lose its UNESCO status. More importantly, this could lead to the loss of irreplaceable archaeological and palaeontological resources (Durand, 2007; Boyd, 2008).

\section{Legislative requirements}

\section{National guidelines}

South Africa possesses some of the world's most comprehensive and progressive legislation for the protection and conservation of environmental, archaeological and palaeontological resources such as the National Environmental Management Act (Act no. 107 of 1998), the Environmental Conservation Act (Act no.73 of 1989), the National Heritage Resources Act (Act no. 25 of 1999) and the Mineral and Petroleum Resources Development Act (Act no. 28 of 2002). In terms of the World Heritage Convention Act (Act no.49 of 1999), the unnatural disturbance, pollution and degradation of the environment must be avoided, or where they cannot be avoided, mitigated.

In theory, the abovementioned laws, regulations and guidelines provide comprehensive support for the conservation and sustainable development and use of archaeological and palaeontological resources of the COHWHS. In practice however it has been found that there is a lack of expertise and resolve regarding the effective assessment, management and implementation of legislature regarding archaeological and palaeontological resources. In addition, it seems that little progress has been made regarding the effective implementation of national environmental guidelines (Deacon, 2007; Fourie, 2007; Van Eeden et al., 2009). The inability of government agencies to implement the necessary legislative procedures and the absence of dynamic management networks within the national/provincial structure in South Africa cause frustration and confusion amongst various stakeholders, including mining companies, heritage authorities, archaeological and palaeontological NGOs, environmental consultants and public interest groups. This is an issue that should be analysed and urgently addressed in order to identify 
potential measures to improve the efficacy of the management of the archaeological and palaeontological terrains on a national and a provincial level (Deacon, 2007).

Environmental Impact Assessments (EIAs) and Environmental Management Plans (EMPs) are often complicated by conflicting interpretations of legislation. The legislative requirements of archaeological and palaeontological specialist studies are often ranked lower in priority compared to other laws and regulations required for proposed mining development. The National Heritage Resources Act (Act no.25 of 1999) was only officially promulgated during the same year as the inscription of the COHWHS and the Department of Arts and the South African Heritage Resources Agency (SAHRA) has since then been attempting to achieve effective and efficient implementation of these guidelines, which calls for a proactive, dynamic and integrated approach towards environmental management (Fourie 2007).

In addition to the aforementioned national legislative requirements, there are a number of international regulations aimed at the sustainable development and conservation of archaeological and palaeontological resources which can be used as guidelines for the development and implementation of heritage policies for South Africa.

\section{International Guidelines}

The World Bank stipulates in the Performance Standard 8 of the International Finance Corporation (IFC) guidelines how cultural and natural heritage resources should be used sustainably and be conserved during projects, development and operations. In accordance with the Convention Concerning the Protection of the World Cultural and Natural Heritage, Performance Standard 8 aims to protect irreplaceable cultural heritage and to guide clients on protecting cultural heritage in the course of business operations (IFC Guidelines, 2006).

The United Nations Educational, Scientific and Cultural Organization (UNESCO) is dedicated to the identification, protection and preservation of cultural and natural heritage sites which are considered to be of outstanding value to humanity. UNESCO World Heritage Sites include natural features, such as forests, mountains, or man-made structures that are recognised for their cultural or physical significance to the international community (UNESCO, 2008). Several World Heritage Sites, both cultural and natural have been inscribed by UNESCO since 1999.

UNESCO's World Heritage Committee is responsible for the implementation of the World Heritage Convention, the management of the World Heritage Fund, the identification and inscription of Wold Heritage Sites and also decides on the inscription or deletion of sites on the List of World Heritage in Danger.

As defined in Articles 1 and 2 of the Convention, a World Heritage Site can be inscribed on the List of World Heritage in Danger by the Committee when it finds that the condition of the site corresponds to one or more of the criteria outlined in Section 177 of the Convention which deals with the degradation of Heritage Sites. The potential dangers which pose a risk to a World Heritage Site are described in Section 179 (b) of the Convention and refers to those threats that would have deleterious effects on its inherent characteristics (UNESCO, 2008). The most serious threats to the geological and ecological integrity of the COHWHS are certain agricultural practices, urbanisation and mining (Durand, 2007; 2008).

TD, 6(1), July 2010, pp. $73-92$. 


\section{Area of investigation}

\section{Cradle of Humankind World Heritage Site}

The Cradle of Humankind World Heritage Site is located approximately fifty kilometres northwest of Johannesburg and lies across the border between Gauteng and Northwest Provinces. This 47000 hectare area is exceptionally rich in archaeological and palaeontological resources. The COHWHS extends from Krugersdorp in the south to the Hartebeespoort Dam in the north. This region is not only important from a research and conservation perspective, but also has significant business and recreational value.

The COHWHS contains more than two hundred caves and fossil localities situated in the Malmani Dolomite of the Chuniespoort Group which dominates the geology of the area. Due to the soluble nature of dolomite, the region is pock-marked with solution cavities, caves, sinkholes, dolines and springs situated between gently undulating hills which is typical of a karst landscape.

More than a century ago, there was a growing demand on the Witwatersrand for lime which was used to neutralise the acid solution which remained after the extraction of gold from the crushed ore. Limestone mines appeared in the Krugersdorp District soon after the Main Reef was discovered along the length of the Witwatersrand Supergroup. Several of the fossil sites in the COHWHS were initially utilised as limestone mines.

\section{Palaeontology}

The Plio-Pleistocene palaeontological sites in South Africa are situated within the Malmani Subgroup dolomites in the northern part of South Africa. The abundance of the dolomitic caves in this region is the main reason for the concentration of heritage resources in the COHWHS. These dolomitic caves provided shelters for hominids and other predators from approximately 3 million years ago. The bony remains of their prey collected in the caves as part of the cave fill. The reason for the remarkable preservation of fossil bones in the COHWHS is due to the alkaline environment created by the dolomite and calcite formations which allows the bones to be preserved and be mineralised over time.

There are approximately 40 known fossil-bearing sites within the COHWHS and many that fall outside the borders of the COHWHS. Thirteen of the better known sites, which include sites that yielded hominid remains, were inscribed as part of the description and declaration of the COHWHS. These are: Sterkfontein Caves, Bolt's Farm, Cooper's Cave, Kromdraai, Swartkrans, Plover's Lake Cave, Minnaar's Cave, Gondolin Cave, Gladysvale Cave, Haasgat Cave, Drimolen, Motsetsi, and Wonder Cave (See Fig. 1).

The first recorded discovery of fossils at the Sterkfontein Caves was made by a group of students from the Marist Brothers College in Johannesburg in 1895. Although a member of the South African Geological Society, David Draper, advised that these caves were worthy of conservation due to their limestone formations and palaeontological value, mining continued in the vicinity (Hilton-Barber and Berger, 2002). The discovery of the skull of a juvenile apeman at Taung in the Northwest Province, in 1924, sensitised people to the importance of the fossils that were 
associated with limestone deposits in South Africa. This apeman was named Australopithecus africanus, or southern ape of Africa (Dart, 1925).

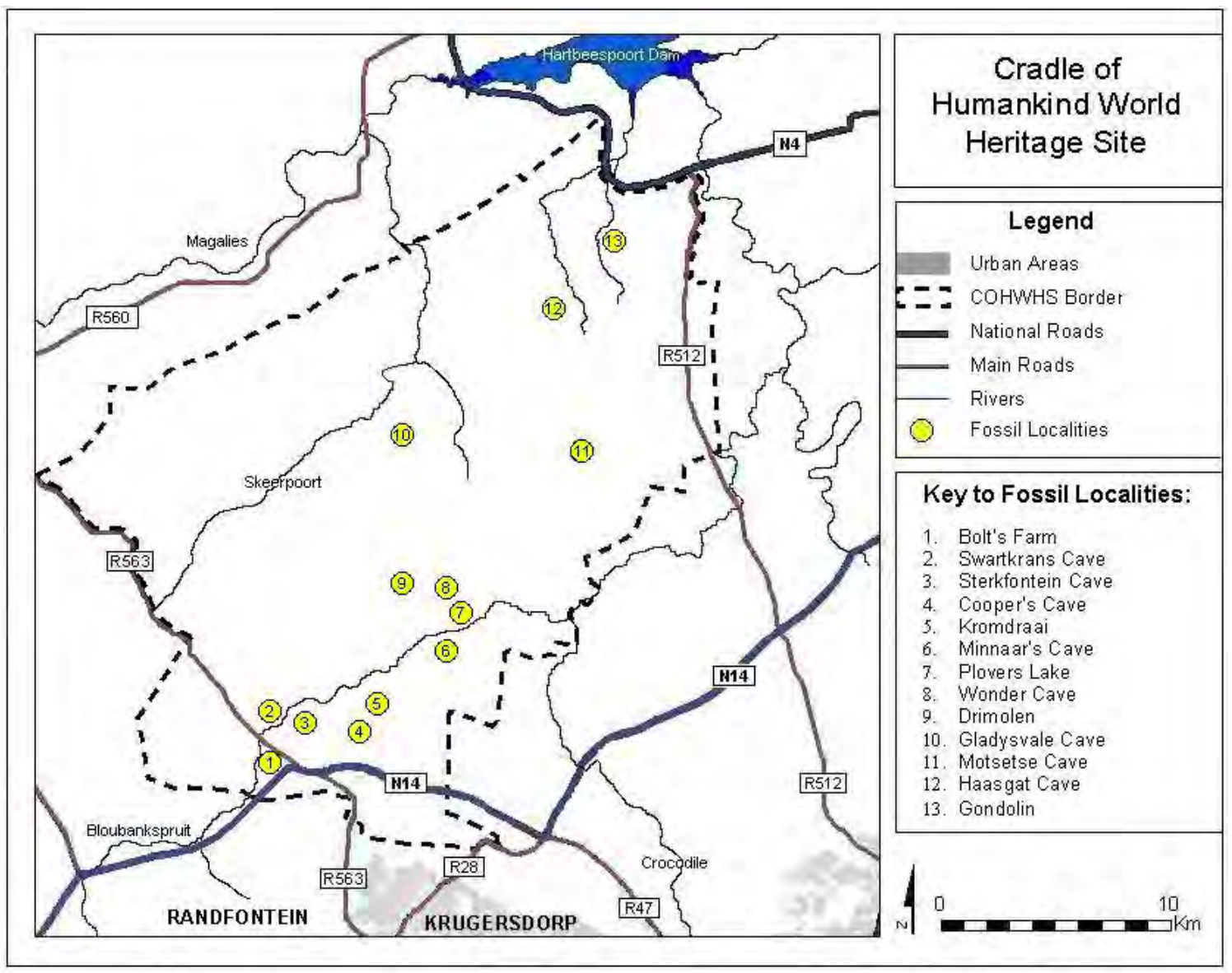

Figure 1: The most important palaeontological sites in the COHWHS as inscribed by UNESCO

Robert Broom of the Transvaal Museum discovered the first adult apeman skull, albeit very incomplete and fragmentary, at Sterkfontein in 1936 (Broom, 1936). Broom originally named this apeman fossil Australopithecus transvaalensis, but later changed it to Plesianthropus transvaalensis. However, in the light of many subsequent discoveries a convincing argument could be made that these genera were actually the same. Plesianthropus transvaalensis was finally renamed to Australopithecus africanus (Broom, 1950).

In 1947 Broom discovered a second adult Australopithecus africanus skull, but this time it was undistorted and almost complete. The new skull was slightly smaller that the first adult apeman skull and it was therefore presumed to be that of a female. This, together with the original binomen Plesianthropus transvaalensis, inspired the nickname Mrs. Ples by which this fossil became known (Broom, 1950).

Many thousands of fossils have been excavated at Sterkfontein since then; the majority of which are the remains of mammals which were the prey of carnivores that used the prehistoric caves as their lairs (Brain, 1981). The Sterkfontein fossil site, which has to date yielded more than half of all the hominid fossils on earth, may be considered to be the world's richest hominid site. 
Fossil excavations are still ongoing at Sterkfontein, making it the hominid site with the longest record of uninterrupted excavations on earth (Hilton-Barber and Berger, 2002).

Robert Broom and his colleagues were responsible for the discovery and exploratory excavations of the palaeontological deposits at Bolt's Farm, Cooper's Cave, Gladysvale, Swartkrans and Kromdraai where the remains of a second type of apeman, Paranthropus robustus were discovered (Broom, 1947). Several other fossil-bearing sites were discovered after Broom's death in 1951, the most important being Gondolin, Minnaar's Cave, Plover's Lake, Haasgat, Drimolen, Motsetsi Cave and Wonder Cave.

\section{Archaeology}

Thousands of stone tools have been discovered in the COHWHS. These tools include Oldowan hand axes, Acheulean points and microliths. In younger strata pot shards and other artefacts dating from the Iron Age have been unearthed.

Several dating techniques have been used to date the different palaeontological sites in the COHWHS, these include: palaeomagnetic surveys, electron spin resonance assessments, uranium decay series measurements and biochronological and archaeological comparisons. The palaeontological sites which yielded fossils and tools associated with Paranthropus and early Homo were dated by using these techniques at between 2 million and 800000 years (Herries et al., 2009).

One of the most important discoveries of an archaeological nature in the COHWHS was the excavation of burnt bones at Swartkrans. These bones were burnt in a fireplace inside the prehistoric cave at temperatures of up to $500^{\circ} \mathrm{C}$ which is interpreted as the oldest proof for the controlled use of fire (Brain, 1981). The age of this fireplace has been estimated to be between 1 million and 1.5 million years old (Brain, 1983).

\section{Threats to the COHWHS}

\subsection{Mining}

\subsubsection{Gold}

Mining in the vicinity of the COHWHS dates back to the Early Iron Age period where the descendants of the Sotho and Tswana populations were respected for their metal work and were part of a dynamic trading community. Other commodities that have been mined in the area include gold, dolomite and limestone. The Blaaubankspruit Gold Mine was proclaimed in 1875 and the Kromdraai gold mine (in the COHWHS) in 1885. George Harrison discovered the Main Reef of the Witwatersrand Supergroup on the Farm Langlaagte in 1886. This reef turned out to be the richest and most extensive gold deposit in the world (Mendelsohn \& Potgieter, 1986). During the subsequent year, the Main Reef was traced along the rest of the Witwatersrand from the West Rand to the East Rand (Viljoen \& Reimold, 2002).

As the mining strategies changed from small scale open cast and shallow pit mining methods along the outcrop of the Main Reef to underground mining, new techniques had to be 
developed to access the rich gold deposits which extended far underground. To extract the gold of the Witwatersrand, a new mining technique namely deep mining was developed and perfected in South Africa and has become the proven way to excavate gold in the world. Deep mining involves the excavation of the gold-bearing reefs, leaving stopes which are connected via incline and vertical shafts while pillars of natural rock, wood or concrete support the hanging wall.

The gold mines of South Africa have been the foundation of the country's economic growth for the past century, producing up to 35\% of the world's gold. Gold mining in the West Rand area remains one of the most prominent contemporary industries in South Africa with approximately $45 \%$ of gold mining originating from the Witwatersrand Basin (Boyd, 2008). Mining companies with interest in this mineral rich area include Anglo Gold Ashanti Limited, Durban Roodepoort Deep Gold Limited, Ergo Mining (Pty), Gold Fields, Harmony Gold Mining Company Limited (now part of Rand Uranium), Mintails South Africa, Pamodzi Gold (West Rand Mining Operations), Randgold and Exploration Company (Ltd) and the Witwatersrand Consolidated Gold Resources (Ltd), amongst others (Chamber of Mines, 2008).

\subsubsection{Uranium}

Radioactive metals were first discovered in the Witwatersrand Supergroup in 1915. The first plant that produced uranium commercially was built at West Rand Consolidated Mines in 1952 when the strategic importance of nuclear weapons became clear. Waste material from the gold mines containing uranium and its radioactive daughter products is dumped in slimes dams, wash down rivers and drain into the groundwater (Coetzee et al., 2006). Although some uranium extraction takes place on the West Rand (e.g. Uranium One in Carletonville), it is done on a small scale and is not economically viable. Plans to open a more extensive uranium extraction plant are underway in the form of Rand Uranium on the old Harmony Gold property in Randfontein. Great quantities of uranium has been, and still is dumped in the slimes dams on the West Rand (Coetzee et al., 2006; Winde, 2009)

\subsubsection{Dewatering the dolomites}

The dolomites of the Malmani Subgroup house an extensive karstic aquifer that supplies most of the groundwater in these provinces (Hobbs and Cobbing, 2007a). The dolomitic rocks which overlie the gold-bearing quartzite rocks of the Witwatersrand Supergroup along the southern part of Gauteng and North West Province had to be dewatered for deep mining to commence (Warwick et al., 1987; Dreybrodt, 1996). The dewatering of the mine disrupted the normal recharge and discharge rates of groundwater, it interfered with the natural flow of groundwater and surface water and it caused sinkholes to be formed in the region (Enslin et al., 1976; Kleywegt \& Pike, 1982; Swart et al., 2003).

\subsubsection{Acid mine drainage (AMD)}

The auriferous layers of the Witwatersrand Supergroup are characterised by their high gold, uranium and pyrite $\left(\mathrm{FeS}_{2}\right)$ content. When pyrite comes in contact with water and oxygen, sulphuric acid $\left(\mathrm{H}_{2} \mathrm{SO}_{4}\right)$ is produced.

The sulphuric acid content in stagnant water in deep mines become concentrated enough to dissolve rock and set the metals it contains free. The most common metals released by sulphuric acid in gold mines on the Witwatersrand include manganese, aluminium, iron, nickel, zinc, 
cobalt, copper, lead, radium, thorium and uranium (Kleywegt, 1977; Venter, 1995; Coetzee et al., 2006). The high iron content of AMD turns the water orange (See Fig. 2).

The gold mines of the Witwatersrand have been dewatered up to a level of $3 \mathrm{~km}$ underground for the best part of a century water. As the mines on the Witwatersrand were abandoned one after the other after WWII, the mine void left by mining, slowly flooded again. The Western Basin Mine Void under Krugersdorp and Randfontein alone constitutes 45 million cubic meters.

In 2002, the springs on the West Rand started to flow again after a century, but this time with AMD containing acid, sulphates and heavy metals. Megaliters of AMD are currently decanting into the Tweelopiespruit and Wonderfonteinspruit from the Black Reef Incline Shaft and the no.17 and 18 Winze Shafts as well as from several springs, boreholes and seepage points (Coetzee and Van Tonder, 2008). The Tweelopiespruit flows through the Krugersdorp Nature Reserve and into the Rietspruit which in turn flows into the Bloubankspruit. The Bloubankspruit, which is a tributary of the Crocodile River, flows through the COHWHS.

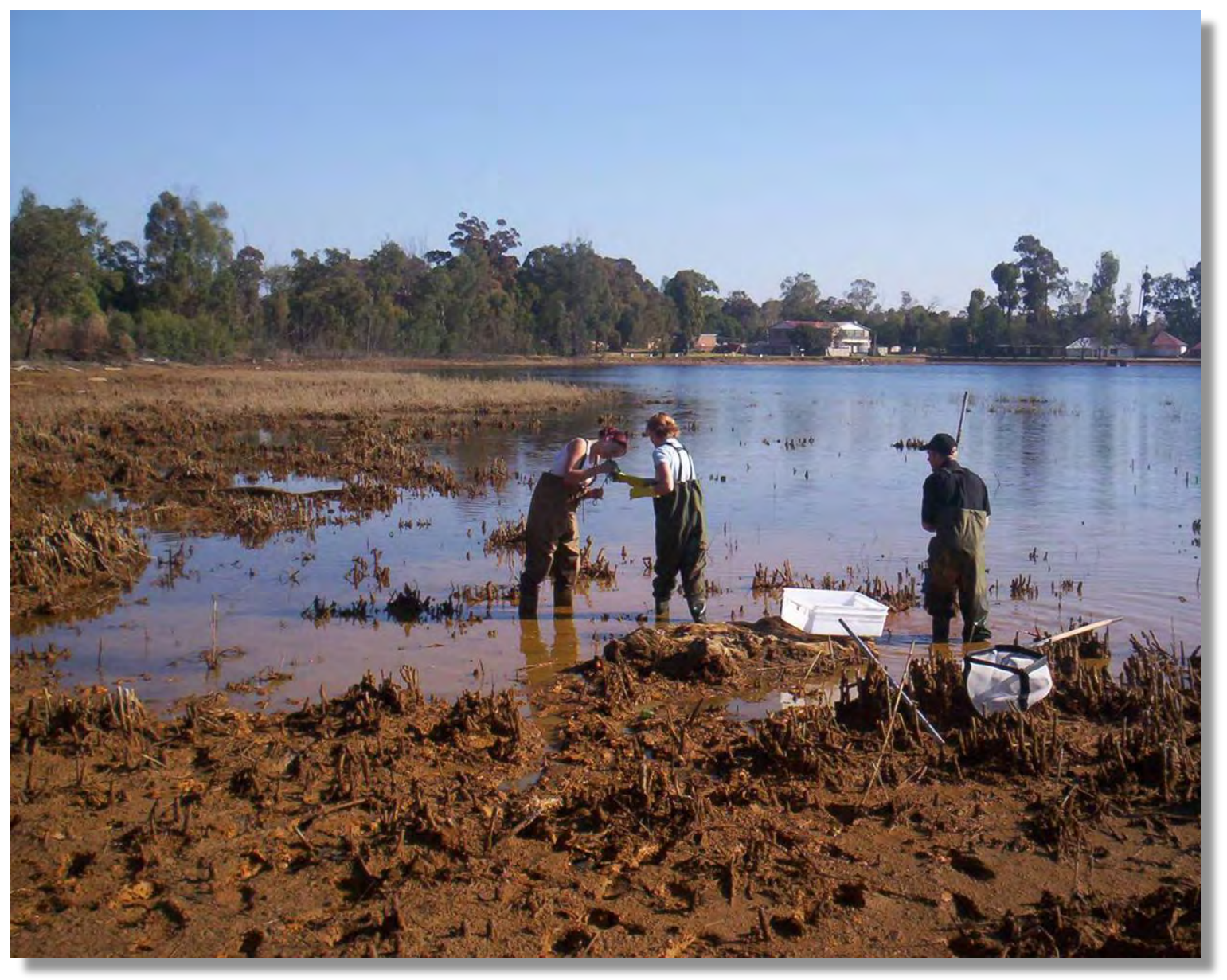

Figure 2: AMD from Harmony Gold Mine in Robinson Lake in Randfontein

The impact of AMD on the groundwater in the proximity of mines is even worse than that on surface water bodies. Pollutants remain stagnant in groundwater for many years whereas pollutants may be flushed out from rivers during heavy rains. AMD reaches the groundwater by permeating through the rock adjacent to the mine void, the recharge of aquifers and by leaching 
from spoil heaps and mine dumps. It was discovered decades ago that slimes dumps that were built on the dolomites tended to be more stable and did not collapse as easily as those built on less permeable surfaces. This stability is caused by the permeable nature of the underlying dolomite into which the water of the slimes dumps drains.

The structural stability of the dolomites in COHWHS is threatened by the influx of AMD into the region. Dolomites and limestone are highly soluble in acid which will lead to accelerated karstification of the affected area. The sulphuric acid in the AMD will dissolve large volumes of rock as it passes over dolomite and through the dolomitic aquifer. Fissures will widen and solution cavities will be created in the process. Dolines and sinkholes will form when the surface collapses into the subterranean void below (Swart et al., 2003; Hodgson et al., 2001).

A high level of sulphates occurs in the groundwater of the region between Harmony Gold Mine and the COHWHS and in the COHWHS itself (Krige, 2006). Sulphates are formed as a byproduct of the chemical reaction between sulphuric acid and dolomite and can therefore be used as an indication of the presence of AMD in a dolomitic region.

\subsection{Tourism and Business Development}

The area between the western part of the Witwatersrand and Magaliesberg Mountains was used for farming from the late $19^{\text {th }}$ Century to the present. Even today there are approximately 700 farms or smallholdings in the COHWHS, many of which are used to produce crops and have livestock (Hamann, 2004). Although gold mining became the primary foundation of the region's, and indeed the country's, economic prosperity after 1886, the focus more recently shifted to include tourism, manufacturing, agribusiness and recreational development (Mogale City Local Municipality, 2008).

Owing to its geographical proximity to major cities and airports like O.R Tambo and Lanseria International Airports, there has been an evident increase in residential and ,light industrial development on the West Rand. The agricultural, horticultural and animal husbandry practices in this area tend to be more intensive than in neighbouring provinces, where it is more common to have free ranging cattle grazing on natural veld and low density farming. It is reported that the agricultural and farming activities of the Western regions of Gauteng can only sustain high density farming such as piggeries, chicken batteries and feedlots due to limited veld and available water resources (Durand, 2007). Overall, the Gauteng Province seems to be more focused on industrial development and mining.

With reference to tourism development, the Cradle of Humankind World Heritage Site region currently consists of approximately 387 tourist attractions and more than 90 graded establishments. As part of the sustainable development and conservation of the Cradle of Humankind World Heritage Site area, the Gauteng Provincial Government's Management Authority invested an estimated amount of R189 million in roads and bulk infrastructure to develop the site and motivate private sector investment in tourism development. In October 2003, the Gauteng Provincial Government entered into a contract valued at R163 million with Maropeng a'Afrika Leisure (Pty) Ltd for the construction, design and operation of world class visitor exhibition and recreational facilities at the Cradle of Humankind World Heritage Site. This Public Private Partnership is an unique concession agreement, requiring Maropeng a'Afrika Leisure (Pty) Ltd to pay an annual concession fee that the government will invest in community

TD, 6(1), July 2010, pp. $73-92$. 
benefit projects and in scientific research (Gauteng Provincial Government, 2008). In addition to numerous tourist attractions and graded establishments, there are in excess of 175 accommodation establishments, 113 restaurants, 70 conference venues and 44 wedding venues in and around the Cradle of Humankind World Heritage Site. These tourism establishments directly employ an estimated 7000 permanent employees and 2200 casual employees.

In February 2008, the Cradle of Humankind World Heritage Site and Dinokeng Blue-IQ projects received the Sustainable Tourism Investment of the Year award at a gala ceremony at the Hyatt Regency Hotel in Johannesburg. These two Blue-IQ projects are an initiative of the Gauteng Provincial Government to establish geo-spatial tourism destinations in the northwest and the northeast of the province (Mogale City, 2008). It is evident that the economic prosperity of tourism is directly linked to the conservation of archaeological and palaeontological resources found in the Cradle of Humankind World Heritage Site area. As main tourist attraction in this area, the conservation of these resources and the limestone caves associated with the fossillferous deposits, is therefore of paramount importance for the sustainable development of the regional tourism industry.

Although it is essential that these irreplaceable archaeological, palaeontological and geological resources need to be conserved in order to protect the status of the COHWIS, there is increasing evidence that the decant of mine effluent in the West Rand area threatens the sensitive karst environment of the COHWHS (Durand, 2007; Durand, 2008; Van Eeden et al., 2009).

\section{Potential Risks}

In South Africa and specifically in the COHWHS, the karst system associated with dolomitic environments is threatened by various elements, including groundwater pollution, urban development, vandalism and unauthorized removal of fossils or cave formations by the public, as well as the over-use of natural resources in the area (Durand, 2007). The most significant risk to the archaeological and palaeontological resources in the Cradle of Humankind World Heritage site is associated with surface- and groundwater pollution, more specifically acid mine drainage. AMD decanting from the mine void into the karst system has penetrated the dolomitic Zwartkrans Compartment below the mine property, the Krugersdorp Nature Reserve and the southern part of the COHWHS (Krige, 2006; Oelofse et al., 2007; Hobbs and Cobbing, 2007a; 2007b; Coetzee et al., 2009.). Mine effluent is now decanting from the Zwartkrans Compartment into the Northern dolomitic compartment in the northern part of the COHWHS (Krige, 2006). In addition to the AMD, the COHWHS has also been affected by effluent discharge from municipal waste treatment works, and especially from the Percy Steward Sewage works (Hobbs and Cobbing, 2007a; 2007b).

The solubility and permeability of the sensitive karst system in the Cradle of Humankind World Heritage area makes it especially susceptible to water pollution and environmental degradation. The effects of acid mine drainage on dolomitic environments and karst systems could cause sink holes, irreversible damage to the karst system and surrounding dolomitic environment and irreparable damage to archaeological and palaeontological resources contained in this area. Acid mine drainage has the potential to dissolve any dolomitic geological structure on its dispersion 
route, including the vulnerable dolomitic in the Cradle of Humankind World Heritage Site that accommodates various fossils and archaeological and palaeontological resources (Durand, 2007).

The legacy of environmental mismanagement of the water resources entering the COHWHS is evidently becoming an increasing concern for stakeholders and communities in this area who depend almost entirely on groundwater for drinking and irrigation purposes. Due to the potential harmful effects of acid mine drainage in this area, negative impacts pose severe risks to the health and well-being of humans, animals and the environment, as well as the status of the Cradle of Humankind World Heritage Site (Durand, 2007; Van Eeden et al., 2009; Winde, 2009). In order to quantify and comprehend the significance of potential impacts on archaeological and palaeontological resources in the Cradle of Humankind World Heritage Site, an impact assessment is required.

\section{Impact Assessment}

\subsection{Impact assessment rating}

The impact rating process is designed to provide a numerical rating of the various environmental impacts identified by use of the "Input-Output" model. The purpose of the impacts assessment process is not to provide an incontrovertible rating of the significance of various aspects, but rather to provide a structured, traceable and defendable methodology of rating the relative significance of impacts in a specific context (DWA and PGS, 2009). The significance rating process follows the established impact/risk assessment formula: Significance $=$ Consequence $\mathrm{x}$ Probability; where: Consequence" = Severity + Spatial Scale + Duration; and Probability is determined with reference to industry knowledge and instances of impacts happening in similar instances. The significance rating of archaeological and palaeontological sites is generally also based on four main criteria:

- $\quad$ Site integrity (i.e. primary vs. secondary context),

- Amount of deposit, range of features (e.g. stone tools and enclosures),

- Uniqueness and

- $\quad$ Potential to answer present research questions.

Management actions and recommended mitigation are expressed as follows:

A - No further action necessary;

B - Mapping of the site and controlled sampling required;

C - Preserve site, or extensive data collection and mapping of the site; and

D - Preserve site

$T D$, 6(1), July 2010, pp. $73-92$. 
For the purpose of the impact and risk assessment of archaeological and palaeontological resources in the COHWHS, site significance classification standards prescribed by the South African Heritage Resources Agency (SAHRA), approved by the Association for Southern African Professional Archaeologists (ASAPA) for the Southern African Development Community (SADC), were utilised. The integrated impact assessment approach and associated ratings that were utilised in this assessment have been summarised in the following tables (National Heritage Resources Act, 1999 and DWA and PGS, 2009):

\section{Site Significance (SAHRA and ASAPA)}

\begin{tabular}{|l|lll}
\hline FIELD RATING & GRADE & SIGNIFICANCE & RECOMMENDED MITIGATION \\
\hline $\begin{array}{l}\text { National Significance } \\
\text { (NS) }\end{array}$ & Grade 1 & - & Conservation; National Site nomination \\
\hline $\begin{array}{l}\text { Provincial Significance } \\
\text { (PS) }\end{array}$ & Grade 2 & - & Conservation; Provincial Site \\
\hline $\begin{array}{l}\text { Local Significance (LS) } \\
\text { nocal Significance (LS) }\end{array}$ & Grade 3A & High Significance & Conservation; Mitigation not advised \\
\hline $\begin{array}{l}\text { Generally Protected A } \\
\text { (GP.A) }\end{array}$ & - & High Significance & Mitigation (Part of site should be \\
\hline $\begin{array}{l}\text { Generally Protected B } \\
\text { (GP.B) }\end{array}$ & - & High / Medium \\
\hline $\begin{array}{l}\text { Generally Protected C } \\
\text { (GP.C) }\end{array}$ & - & Significance & Mitigation before destruction \\
\hline & & Medium Significance & Recording before destruction \\
\hline
\end{tabular}




\section{Severity (Positive and Negative Impacts)}

\begin{tabular}{|l|l|}
\hline 5 & $\begin{array}{l}\text { Very significant impact/total destruction of a highly valued species, habitat or ecosystem in } \\
\text { the environment; or Irreparable damage to/destruction of highly valued items of great cultural } \\
\text { significance }\end{array}$ \\
\hline 4 & $\begin{array}{l}\text { Serious impairment of ecosystem function or Serious social issues/Permanent damage to } \\
\text { items of cultural significance }\end{array}$ \\
\hline 3 & $\begin{array}{l}\text { Moderate negative alteration of ecosystem functioning or Moderately important social issues } \\
\text { and/or moderately significant damage to items of cultural significance }\end{array}$ \\
\hline 2 & $\begin{array}{l}\text { Minor effects not affecting ecosystem functioning or Minor Impacts on the local population, } \\
\text { repairable over time. Temporary impairment of the availability of items of cultural } \\
\text { significance }\end{array}$ \\
\hline 1 & $\begin{array}{l}\text { Insignificant effects on the biophysical environment or Insignificant social issues / low-level } \\
\text { repairable damage to commonplace structures. }\end{array}$ \\
\hline
\end{tabular}

\section{Spatial Scale/Extent}

\begin{tabular}{|c|l|}
\hline 5 & National/International (Neighbouring countries or abroad) \\
\hline 4 & Provincial or Regional (Gauteng Province) \\
\hline 3 & Regional (substantially beyond site boundary; more than $5 \mathrm{~km}$ ) \\
\hline 2 & Local (beyond site boundary and affects neighbours; up to $5 \mathrm{~km}$ from site) \\
\hline 1 & Site (does not extend beyond site boundary, Cradle of Humankind area) \\
\hline
\end{tabular}

\section{Duration}

\begin{tabular}{|c|l|}
$\mathbf{5}$ & Permanent/Irreversible (more than 50 years) \\
\hline $\mathbf{4}$ & Long Term $(26$ to 50 years or beyond) \\
\hline $\mathbf{3}$ & Medium Term $(5-25$ years $)$ \\
\hline $\mathbf{2}$ & Medium-Short Term (1-4 years) \\
\hline $\mathbf{1}$ & Short term (Less than a year) \\
\hline
\end{tabular}

$T D$, 6(1), July 2010, pp. $73-92$. 


\section{Probability}

\begin{tabular}{|c|l|}
\hline $\mathbf{5}$ & Certain/ Normally happens in cases of this nature (81-100\% chance) \\
\hline $\mathbf{4}$ & Will more than likely happen $(61-80 \%$ chance $)$ \\
\hline $\mathbf{3}$ & Could happen and has happened here or elsewhere (41-60\% chance) \\
\hline $\mathbf{2}$ & Has not happened yet, but could (21-40\% chance) \\
\hline $\mathbf{1}$ & Conceivable, only very specific circumstances, not likely $(0-20 \%$ chance $)$ \\
\hline
\end{tabular}

\subsection{Impact assessment and AMD in the COHWHS}

The COHWHS is considered to be of national and international significance and consequently classified as a site of National Significance (NS, Grade 1) (National Heritage Resources Act, 1999). As indicated in Table 1, this World Heritage Site may be severely threatened by the potential impact of surface- or groundwater pollution and the infiltration of acidic water with $\mathrm{pH}$ values between 2-4 into the sensitive dolomitic environment. The risks posed to the Cradle of Humankind World Heritage Site is due to the solubility and permeability of the sensitive karst system that could cause sinkholes, irreversible damage to the karst system and surrounding dolomitic environment and irreparable damage to archaeological and palaeontological resources contained in this area (Durand, 2007). Recent reports indicate that acidity levels of between $\mathrm{pH} 2$ and $\mathrm{pH} 4$ have already been recorded and documented, verifying the possibility of a medium to high significance impact assessment rating to the COHWHS (Van Eeden et al., 2009, Hobbs and Cobbing, 2007a and Boyd 2008).

In order to mitigate these impacts or risks, the decanting of acid mine drainage from mine workings on the West Rand that causes these impacts and associated surface- and groundwater pollution, must be ceased. Alternatively, where the activities associated with the impacts cannot be ceased, it must be mitigated. As indicated in Table 2, this implies that the mine effluent (acid mine drainage and polluted water) must be treated at a water treatment plant and a programme must be implemented to continuously monitor and manage water quality (Hobbs and Cobbing, 2007a; Boyd, 2008; Coetzee and Van Tonder, 2008). The effective implementation of these mitigation measures would require integrated cooperation between various stakeholders and assist to restore water quality to acceptable levels in the Cradle of Humankind World Heritage area. Ultimately, the mitigation and restoration of water quality in the region may decrease the risks and associated impacts significance rating from medium-high to medium-low.

\section{Conclusion}

Environmental management is a multi-disciplinary concept that is especially important in large scale industrial developments such as gold mining, that have the potential to negatively affect the environment and its resources. Although South Africa possesses some of the world's most progressive environmental guidelines and legislation, the practical implementation of these 
guidelines and recommendations by specialists are often constrained by limitations such as a lack of authority, lack of funding, lack of human resources, a lack of proactive environmental management and pressing time constraints (Deacon, 2007; Fourie, 2007). The ineffective implementation of national guidelines and legislative requirements can subsequently lead to environmental disasters that are difficult to mange or control such as water pollution, health risks and environmental degradation (Van Eeden et al., 2009).

Gold mining and mineral extraction on the West Rand has played an important role in the socio-economic development of South Africa; however, the negative impacts and legacies of environmental mismanagement are becoming an increasing concern for the communities and environmental stakeholders, especially on the West Rand, including the COHWHS (Coetzee et al., 2006; Boyd, 2008; Van Eeden et al., 2009).

AMD emanating from the mine void on the West Rand poses a threat to the structural stability of the karst system of the region. Acid containing mine effluent may lead to irreparable damage to the archaeological and palaeontological resources in the COHWHS (Durand, 2007). In addition, it may pose health, safety and environmental risks to surrounding communities (Van Eeden et al., 2009). Site significance ratings for the Cradle of Humankind World Heritage Site has been classified as being medium-high.

In terms of UNESCO criteria, the site could risk losing its World Heritage Site status if these impacts and risks are not mitigated. Where a property has deteriorated to the extent that it has lost those characteristics which determined its inclusion in the World Heritage List, the UNESCO Committee may consider the deletion of a property or site from the World Heritage List (UNESCO, 2008).

An integrated mitigation plan must be implemented by all the stakeholders concerned, including governmental authorities, mining companies and interest groups, followed by continuous water management and monitoring (Hobbs and Cobbing, 2007a; 2007b). Ultimately, the integrated significance of environmental management as a multi-disciplinary concept must be understood before it can be effectively implemented. The medium-high significance ratings of irreplaceable heritage in the COHWHS may be reduced by prompt and decisive intervention.

The poisoning of the water on which thousands of people rely for drinking and farming purposes, the loss of the UNESCO status and the resulting loss of potential income in the form of tourism may be considered to be a crime towards the people of South Africa. The damage to the unique palaeoanthropological wealth of the COHWHS, which is essential for our understanding of human evolution, may be considered to be a crime against humanity.

\section{References}

Boyd, M. (2008) Collective response to a 120-year old conundrum. Mining, June-September 2008, pp. 3-13.

$T D, 6(1)$, July 2010, pp. $73-92$. 
Brain, C.K. (1981) The hunters or the hunted? An introduction to African cave taphonomy. The University of Chicago Press, Chicago, 376 p.

Brain, C.K. (1983) Structure and stratigraphy of the Swartkrans cave in the light of new excavations. In: C.K. Brain (editor) Swartkrans: a cave's chronicle of early man. Transvaal Museum Monograph No. 8.

Broom, R. (1936) A new fossil anthropoid skull from South Africa. Nature, 138, pp. 468-488.

Broom, R. (1947) Discovery of a new skull of the South African ape-man, Plesianthropus. Nature 159, p. 672.

Broom, R. (1950) Finding the Missing Link. Watts, London, 104 p.

Chamber of Mines (2008) http://www.chamberofmines.co.za/ (Accessed on 06 November 2008).

Coetzee, H., Chirenje, E., Hobbs, P. and Cole, J. 2009. Ground and airborne geophysical surveys identify potential subsurface acid mine drainage pathways in the Krugersdorp Game Reserve, Gauteng Province, South Africa. 11 ${ }^{\text {th }}$ SAGA Biennial Technical Meeting and Exhibition, Swaziland, 16-18 September 2009, pp. 461-170.

Coetzee, H. and Van Tonder, D. 2008. Regional Closure Strategy for the West Rand Goldfields. Council for Geoscience Report No: 2008-0253, 94 p.

Coetzee, H., Winde, F. and Wade, P.W. (2006) An assessment of sources, pathways, mechanisms and risks of current and potential future pollution of water and sediments in gold-mining areas of the Wonderfonteinspruit catchment. Water Research Commission, Report No. 1214/06.

Dart R.A. (1925) Australopithecus africanus: The Man-Ape of South Africa. Nature 115 (2884), pp. 195-199.

Deacon, J, (2007) A Beginners Guide to Archaeology, SAHRA and the PHRAs, The Digging Stick 24(1), pp. 15-16.

Digby Wells and Associates (DWA) and Professional Graves Solutions (PGS) (2009) Archaeological Impact Assessment (AIA) for the Proposed Kangala Coal Mine on Portions 1 and Remaining Extent of Portion 2 of Wolvenfontein 244 IR in the Delmas Area, Mpumalanga Province, Unpublished Report, November 2009, Randburg.

Dreybrodt, W. (1996) Principles of early development of karst conduits under natural and manmade conditions revealed by mathematical analysis of numerical models. Water Resources Research 32, pp. 2923-2935.

Durand, J.F. (2007) Challenges associated with living in karst environments such as the historical Cradle of Humankind, New Contree 54, pp. 75-98. 
Durand, J.F. (2008) Die karst-ekologie van Suid-Afrika met spesiale verwysing na die Wieg van die Mensdom Wêrelderfenisgebied. Suid-Afrikaanse Tydskrif vir Natuurwetenskap en Tegnologie, 24(4), pp. 5-15.

Enslin, J.F., Kleywegt, R.J., Beukes, J.H.T. and Gordon-Welsh, J.F. (1976) Artificial recharge of dolomitic ground-water compartments in the Far West Rand Gold Fields of South Africa. Geological Survey of South Africa, Report 0249.

Fourie, W. (2007) Archaeological Impact Assessments within South African Legislation Paper presented at the Archaeological Resources Management Workshop, 17 May 2007, South African Archaeological Bulletin 63 (187), pp. 77-85.

Gauteng Provincial Government (2008) A Win for the Cradle of Humankind World Heritage Site, 8 May 2008, http://www.gpg.gov.za/docs/pr/2008/pr0508.html

Hamann, H. (2004) A town like no other. Randfontein, more than 75 years of history. Com Printers, Randfontein.

Herries, A.I.R.; Curnoe, D. and Adams, J.W. (2009) A multi-disciplinary seriation of early Homo and Paranthropus bearing palaeocaves in southern Africa. Quaternary International 202, pp. 14-28.

Hilton-Barber, B. and Berger, L.R. (2002) The official field guide to the Cradle of Humankind: Sterkfontein, Swartkrans, Kromdraai \& Environs World Heritage Site, Cape Town, 212 p.

Hobbs, P.J. and Cobbing, J.E. (2007a) Hydrogeological assessment of Acid Mine Drainage impacts in the West Rand Basin, Gauteng Province, Report no.CSIR/NRE/WR/ER/2007/0097/C. CSIR/THRIP, Pretoria. South Africa.

Hobbs, P.J. and Cobbing, J.E. (2007b) The hydrogeology of the Krugersdorp Game Reserve Area and implications for the management of mine water decant, Proceedings of the Groundwater Conference, Bloemfontein, South Africa, 8-10 October 2007.

Hodgson, F.D.I., Usher, B.H., Scott, R., Zeelie, S., Cruywagen, L.M. and De Necker, E. (2001) Prediction techniques and preventative measures relating to the post-operational impact of underground mines on the quality and quantity of groundwater resources, Water Research Commission of South Africa, Report No. 699/1/01, 285 p.

International Finance Corporation (IFC) Guidelines (2006) Performance Standard 8, World Bank Guidelines, 30 April 2006.

Kleywegt, R.J. (1977) Memorandum oor die moontlike gevaar wat geskep word deur water vanaf die 'Western Areas Gold Mining Co. Ltd.' na die Rietspruit te laat vloei. Geological Survey of South Africa Technical Report No. 0141.

Kleywegt, R.J.and Pike, D.R. (1982) Surface subsidence and sinkholes caused by lowering of the dolomitic water-table on the Far West Rand Gold Field of South Africa. Annals of the Geological Survey of South Africa 16. 
Krige, G. (2006) Hydrological/chemical aspects of the Tweelopie/Riet/Blaauwspruit with specific reference to the impact water, decanting from the Western Basin Mine Void has on the system. EIA Report prepared for Harmony Gold Mining Limited.

Mendelsohn, F. \& Potgieter, C.T. (1986) Guidebook to sites of geological and mining interest on the Central Witwatersrand. Geological Society of South Africa \& The South African Institute of Mining and Metallurgy, Johannesburg, $124 \mathrm{p}$.

Mogale City (2008) Cradle of Humankind scoops tourism award by Millicent Kgowedi http://www.mogalecity.gov.za (Accessed on 27 February, 2008).

Mogale City Local Municipality (2008) Integrated Development Plan 2008 - 2009, Johannesburg.

Oelofse, S.H.H., Hobbs, P.J., Rascher, J. and Cobbing, J.E. (2007) The pollution and destruction threat of gold mining waste on the Witwatersrand: a West Rand case study. Paper presented at the $10^{\text {th }}$ International Symposium on Environmental Issues and Waste Management in Energy and Mineral Production (SWEMP, 2007). Bangkok, 1113 December 2007, pp 617-627.

Republic of South Africa, (1989) Environmental Conservation Act, No. 73 of 1989.

Republic of South Africa (1998) National Environmental Management Act, 107 of 1998.

Republic of South Africa (1999a) National Heritage Resources Act, 25 of 1999.

Republic of South Africa (1999b) World Heritage Convention Act, 49 of 1999.

Republic of South Africa (2002) Mineral and Petroleum Resources Development Act, 28 of 2002.

Swart, C.J.U.; James, A.R.; Kleywegt, R.J. \& Stoch, E.J. (2003) The future of the dolomitic springs after mine closure on the Far West Rand, Gauteng, RSA, Environmental Geology, 44(7), pp. 751-770.

United Nations Educational, Scientific and Cultural Organization (UNESCO) World Heritage Centre (2008) Operational Guidelines for the Implementation of the World Heritage Convention, January 2008, France.

Van Eeden, E.S., Liefferink, M. and Durand, J.F. (2009) Legal Issues concerning mine closures and social responsibility of the West Rand, The Journal for Transdisciplinary Research in Southern Africa, 5(1), pp. 51-71.

Venter, A.J.A. (1995) Assessment of the effects of gold-mine effluent on the natural aquatic environment. Unpublished PhD Thesis. Rand Afrikaans University, Johannesburg.

Viljoen, M.J. \& Reimold, W.U. (2002) An introduction to South Africa's geological and mining heritage. Geological Society \& Mintek, Johannesburg. 
Warwick, D.W., Brackley, I.J., Connelly, R.J. and Campbell, G. (1987) The dewatering of dolomite by deep mining in the West Rand, South Africa. In: Barry, B., Wilson, W.L. (eds.), Karst hydrogeology: engineering and environmental applications, Proceedings of the 2nd Multidisciplinary Conference on Sinkholes and Environmental Impacts of Karst, Orlando, USA, pp. 349-358.

Winde, F. 2009. Uranium pollution of water resources in mined-out and active goldfields of South Africa - a case study in the Wonderfonteinspruit Catchment on extent and sources of U-contamination and associated health risks. Proceedings of the International Mine Water Conference 19th - 23rd October 2009, Pretoria, South Africa, pp. 772781. 
Table 1: Summary of potential impacts

\begin{tabular}{|c|c|c|c|c|c|c|c|}
\hline SITE & IMPACT/ RISK & PROBABILITY & $\begin{array}{c}\text { SPATLAL SCALE / } \\
\text { EXTENT }\end{array}$ & DURATION & SEVERITY & $\begin{array}{c}\text { SAHRA \& ASAPA } \\
\text { SITE } \\
\text { SIGNIFICNACE }\end{array}$ & $\begin{array}{c}\text { SIGNIFICANCE } \\
\text { BEFORE } \\
\text { MITIGATION }\end{array}$ \\
\hline $\begin{array}{l}\text { Cradle of Humankind World } \\
\text { Heritage Site consisting of } \\
\text { various caves and fossils in a } \\
\text { sensitive karst system/ } \\
\text { dolomitic environment on the } \\
\text { West Rand, Gauteng Province, } \\
\text { South Africa }\end{array}$ & $\begin{array}{l}\text { Infiltration of } \\
\text { surface- or } \\
\text { groundwater } \\
\text { with pH values } \\
\text { between } 2 \text { to } 4 \\
\text { (or lower) }\end{array}$ & $\begin{array}{c}\text { 3- Could happen and } \\
\text { has happened here or } \\
\text { elsewhere (41-60\% } \\
\text { chance) }\end{array}$ & $\begin{array}{c}3-\text { Regional } \\
\text { (substantially } \\
\text { beyond site } \\
\text { boundary; more } \\
\text { than } 5 \mathrm{~km} \text { ) }\end{array}$ & $\begin{array}{l}5 \text { - Permanent/ } \\
\text { Irreversible (more } \\
\text { than } 50 \text { years) }\end{array}$ & $\begin{array}{c}4 \text { - Serious } \\
\text { impairment of } \\
\text { ecosystem function } \\
\text { or Serious social } \\
\text { issues/ Permanent } \\
\text { damage to items of } \\
\text { cultural significance }\end{array}$ & $\begin{array}{c}\text { National } \\
\text { Significance } \\
\text { (NS) } \\
\text { Grade 1 }\end{array}$ & $\begin{array}{l}\text { Medium to High } \\
\text { significance } \\
\text { (Immediate } \\
\text { Mitigation } \\
\text { required) }\end{array}$ \\
\hline
\end{tabular}

Table 2: Summary of recommended mitigation and management measures

\begin{tabular}{|c|c|c|c|c|c|c|c|}
\hline АСТІИТТY & OBJECTIVES & $\begin{array}{l}\text { MITIGATION/ } \\
\text { MANAGEMENT }\end{array}$ & FREQUENCY & APPLICABLE LAWS/ REGS & ACTION PLANS & $\begin{array}{c}\text { RESPONSIBLE } \\
\text { PERSON }\end{array}$ & $\begin{array}{c}\text { SIGNIFICANCE } \\
\text { AFTER } \\
\text { MITIGATION }\end{array}$ \\
\hline $\begin{array}{l}\text { Decanting of } \\
\text { acid mine } \\
\text { drainage from } \\
\text { mine workings } \\
\text { on the West } \\
\text { Rand causing } \\
\text { Surface- and } \\
\text { groundwater } \\
\text { pollution }\end{array}$ & $\begin{array}{l}\text { To facilitate conservation } \\
\text { and ensure the } \\
\text { protection of geological, } \\
\text { archaeological and } \\
\text { palaeontological } \\
\text { resources in the Cradle } \\
\text { of humankind World } \\
\text { Heritage area }\end{array}$ & $\begin{array}{c}\text { Treatment of } \\
\text { acidic water and } \\
\text { acid mine } \\
\text { drainage being } \\
\text { decanted into the } \\
\text { environment at } \\
\text { water treatment } \\
\text { plant }\end{array}$ & $\begin{array}{l}\text { Continuous } \\
\text { (Long term) }\end{array}$ & $\begin{array}{c}\text { World Heritage Convention Act (Act } \\
\text { no. } 49 \text { of 1999), National } \\
\text { Environmental Management Act (Act } \\
\text { no. } 107 \text { of 1998), Environmental } \\
\text { Conservation Act (Act no. } 73 \text { of } \\
\text { 1989), National Heritage Resources } \\
\text { Act (Act no. } 25 \text { of 1999), and } \\
\text { Minerals \& Petroleum Resources } \\
\text { Development Act (Act no.28 of } \\
\text { 2002) }\end{array}$ & $\begin{array}{c}\text { Effective } \\
\text { treatment of } \\
\text { mine effluent } \\
\text { (acidic/polluted } \\
\text { water), and } \\
\text { Continuous } \\
\text { Hydrological } \\
\text { management and } \\
\text { monitoring }\end{array}$ & $\begin{array}{l}\text { Governmental } \\
\text { departments (i.e. } \\
\text { Local and National } \\
\text { Departments of } \\
\text { Water and } \\
\text { Environmental } \\
\text { Affairs), Mining } \\
\text { Companies and } \\
\text { working groups }\end{array}$ & $\begin{array}{l}\text { Medium-low } \\
\text { significance }\end{array}$ \\
\hline
\end{tabular}

